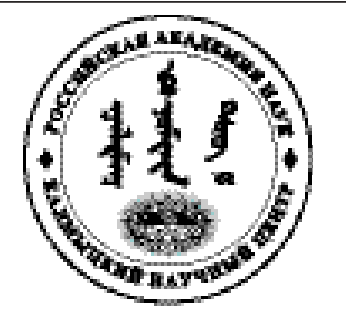

Published in the Russian Federation

Oriental Studies (Previous Name: Bulletin of the Kalmyk Institute

for Humanities of the Russian Academy of Sciences)

Has been issued as a journal since 2008

ISSN: 2619-0990; E-ISSN: 2619-1008

Vol. 13, Is. 5, pp. 1234-1242, 2020

DOI: $10.22162 / 2619-0990-2020-51-5-1234-1242$

Journal homepage: https://kigiran.elpub.ru

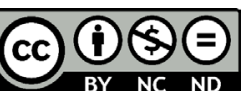

УДК 94 (47)

DOI: $10.22162 / 2619-0990-2020-51-5-1234-1242$

\title{
К вопросу присоединения Средней Азии к России (обзор некоторых башкирских письменных источников второй половины XIX в.)
}

\author{
Минлегали Хусаинович Надергулов ${ }^{1}$, Ильшат Сулейманович Игдавлетов
}

${ }^{1}$ Институт истории, языка и литературы Уфимского федерального исследовательского центра РАН (д. 71, пр. Октября, 450054 Уфа, Российская Федерация)

доктор филологических наук, заведующий отделом

iD 0000-0003-4546-416X. E-mail: nadergul@mail.ru

${ }^{2}$ Институт истории, языка и литературы Уфимского федерального исследовательского центра РАН (д. 71, пр. Октября, 450054 Уфа, Российская Федерация)

кандидат исторических наук, научный сотрудник

iD 0000-0003-2714-9078. E-mail: igdavlet@mail.ru

(C) КалмНЦ РАН, 2020

(С Надергулов М. Х., Игдавлетов И. С., 2020

Аннотация. Введение. Статья посвящена исследованию юго-восточной политики Российской империи во второй половине XIX в., организации походов и присоединению Средней Азии. Цель статьи - введение в научный оборот сведений о юго-восточной политике Российской империи и ходе освоения обширной территории во второй половине XIX в. из арабографичной рукописи путевых записей рядового солдата Хуснияра, хранящейся ныне в Фонде рукописей Института истории, языка и литературы Уфимского федерального исследовательского центра РАН, которая впервые исследуется как исторический источник. Для сравнения привлекается опубликованный источник - заметки статского советника М. Бекчурина. Результатыл. Сегодня, когда юго-восточные границы России практически вернулись к рубежам начала XVIII в., актуальным и практически целесообразным является исследование темы истории установления взаимоотношений с Казахстаном и Средней Азией. Сведения статского советника М. Бекчурина раскрывают экономические цели правительства, когда российская промышленность и торговля искали новые рынки сбыта продукции. М. Бекчурин дает свои предложения для улучшения роста торговли. Рукопись путевых записей Хуснияра отражает наблюдения рядового солдата, его отношение и переживания как мусульманина в походе против единоверцев. Источник позволяет представить набор и маршрут одного из военных формирований. Оба документа дают возможность представить исследуемый регион в конце XIX в. В настоящее вре- 
мя на этой территории существуют самостоятельные страны уже с другими государственными границами, и этнический состав многих населенных пунктов значительно изменился.

Ключевые слова: путевые записи, Мирсалих Бекчурин, Хуснияр, Средняя Азия, Андижан, Туркестан, юго-восточная внешняя политика России

Благодарность. Исследование проведено в рамках государственной субсидии - проект «Духовная культура тюркских народов Южного Урала» (номер госрегистрации: АААА-А17-117040350082-3).

Для цитирования: Надергулов М. Х., Игдавлетов И. С. К вопросу присоединения Средней Азии к России (обзор некоторых башкирских письменных источников второй половины XIX в.) // Oriental Studies. 2020. T. 13. № 5. C. 1234-1242. DOI: 10.22162/2619-0990-2020-51-5$1234-1242$

UDC 94 (47)

DOI: $10.22162 / 2619-0990-2020-51-5-1234-1242$

\title{
Annexation of Central Asia to Russia Revisited: A Review of Some Mid-to-Late 19 $^{\text {th }}$-Century Bashkir Written Sources
}

\author{
Minlegali Kh. Nadergulov ${ }^{1}$, Ilshat S. Igdavletov ${ }^{2}$ \\ ${ }^{1}$ Institute of History, Language and Literature of the Ufa Federal Research Centre of the RAS (71, \\ Oktyabrya Ave., Ufa 450054, Russian Federation) \\ Dr. Sc. (Philology), Head of Department \\ iD 0000-0003-4546-416X. E-mail: nadergul@mail.ru
}

${ }^{2}$ Institute of History, Language and Literature of the Ufa Federal Research Centre of the RAS (71, Oktyabrya Ave., Ufa 450054, Russian Federation)

Cand. Sc. (History), Research Associate

iD 0000-0003-2714-9078. E-mail: igdavlet@mail.ru

(C) KalmSC RAS, 2020

(C) Nadergulov M. Kh., Igdavletov I. S., 2020

\begin{abstract}
Introduction. The article studies southeastern policies of the Russian Empire in the second half of the $19^{\text {th }}$ century, its campaigns and the annexation of Central Asia. Goals. The work analyzes reasons for the activation of foreign policy in the region during the mentioned period. The course and goals of the conquest of the Khanates of Kokand and Khiva, Emirate of Bukhara are considered. Materials. The paper investigates data contained in reports by the State Councilor M. Bekchurin, and one more document - Arabic-script travel records (manuscript) by a private soldier Husniyar currently stored at the Manuscript Collection of the Institute of History, Language and Literature (Ufa Federal Research Centre of the RAS) and for the first time studied as a historical source. Results. Messages about the beauty of Eastern cities and Asian wealth had long attracted attention of Russian monarchs. Finally, Russia's attempts to penetrate into Central Asia were crowned with success. In just two decades, the vast country further extended its borders far to the south and became a neighbor of another one - the British Empire. Nowadays, the study of the history of establishing relations with Kazakhstan and Central Asia, when the southeastern borders of Russia almost returned to those of the early $18^{\text {th }}$ century, is relevant and practically expedient. Reports by State Councilor M. Bekchurin reveal the economic objectives of the government: Russian industry and trade were looking for new markets for their products. So, M. Bekchurin gives his suggestions how to facilitate the growth of trade. The manuscript of Husniyar's travel notes contains observations of an ordinary soldier, his attitude and experience as a Muslim in the campaign against his co-religionists. The source makes it possible to present the set and route of one military formation. Both the documents provide an opportunity to depict this region in the late $19^{\text {th }}$ century. Currently, there are independent countries across this territory with different state borders, and the ethnic composition of many settlements has changed significantly.
\end{abstract}


Keywords: travel notes, Mirsalih Bekchurin, Husniyar, Central Asia, Andijan, Turkestan, Russia's southeastern foreign policy

Acknowledgements. The reported study was funded by government subsidy — project name 'Turkic Peoples of the Southern Urals: Spiritual Culture' (state reg. no. AAAA-A17-117040350082-3).

For citation: Nadergulov M. Kh., Igdavletov I. S. Annexation of Central Asia to Russia Revisited: A Review of Some Mid-to-Late 19 ${ }^{\text {th }}$-Century Bashkir Written Sources. Oriental Studies. 2020. Vol. 13(5): 1234-1242. (In Russ.). DOI: 10.22162/2619-0990-2020-51-5-1234-1242

\section{द}

\section{Введение}

Средняя Азия еще с периода правления Петра I начинает представлять значительный интерес в юго-восточной политике России. Обширный регион привлекает внимание как в торгово-экономическом отношении, так и в военно-стратегическом плане.

Петр Первый, даже при активной западной внешней политике, стремясь к выходу к Балтийскому морю, не упускал из вида огромные восточные границы. Он хорошо понимал, какие экономические выгоды получит государство, если в торговом отношении сможет стать «посредницею» между Азией и Европой [Соловьев 1963: 345]. С правления Петра I в истории российской восточной внешней политики наступает новая эпоха не только в отношении Дальнего Востока, но и в отношении к исламского мира [Бартольд 1977: 391].

Планы проникновения в Среднюю Азию в первой четверти XVIII в. через Персию и Сибирь не имели успеха. Экспедиции во главе И. Д. Бухгольца и А. Бековича-Черкасского закончились неудачами. В итоге правительство решает выбрать другой путь, через Башкирию.

Для реализации планов продвижения во внутреннюю Азию по новому маршруту было необходимо привлечь на свою сторону башкир, яицких казаков и калмыков. Далее предстояло утвердить власть на огромной территории казахских жузов. Поэтому в своей азиатской политике Петр Первый придавал Казахстану большое значение [Буканова 1997: 35].

Появление нового города - Оренбурга - на границе со степью сыграло большую роль в развитии двухсторонних отношений. В том числе активизировались торгово-экономические связи с ханствами Средней Азии. В последующем присоеди- нение казахских жузов к России уже давало новые возможности перед государством. Казахские земли имели значение «ключа и ворот всем азиатским странам и землям» [Витевский 1889: 136].

Развивая дипломатические и торговоэкономические отношения с казахами и среднеазиатскими ханствами, российское правительство начинает активно привлекать и башкир. Одна религия, близость языка, культуры и традиций с казахами и другими народами Средней Азии способствовали налаживанию контактов с южными соседями. Башкиры часто привлекались в качестве переводчиков, купцов, дипломатов и т. д. С началом завоевательных походов в Среднюю Азию они также участвовали вместе с казаками в составе военных экспедиций.

До настоящего времени сохранилось значительное количество составленных башкирами отчетов, журналов, путевых записок, дневников, которые являются ценными источниками, отражающими внешнюю политику Российского государства на Востоке с начала XVIII в. до второй половины XIX в. и полного присоединения Средней Азии к России. Указанные документы содержат множество ценных сведений о социально-экономической, политической и культурной жизни этого обширного региона в данный период. Цель статьи - введение в научный оборот сведений о юго-восточной политике Российской империи и ходе освоения обширной территории во второй половине XIX в. из арабографичной рукописи путевых записей рядового солдата Хуснияра, хранящейся ныне в Фонде рукописей Института истории, языка и литературы Уфимского федерального исследовательского центра РАН (далее - ИИЯЛ УФИЦ РАН), которая впервые исследуется как исторический источник. Для сравнения 
привлекается опубликованный источник заметки статского советника М. Бекчурина.

Сведения М. Бекчурина о Средней Азии

С окончательным присоединением в середине XIX в. всех казахских жузов российское правительство начинает активное продвижение в Среднюю Азию, где на тот момент существовали такие государства, как Бухарский эмират, Кокандское и Хивинское ханства. Это обширное пространство населяли каракалпаки, узбеки, туркмены, киргизы, уйгуры и таджики, в большинстве тюркоязычные народы.

Усиление активизации российского правительства на востоке вызывалось экономическими причинами и обострением противоречий между Российской и Британской империями, так как Средняя Азия примыкала к индийским владениям Англии.

В июне 1864 г. из городов Перовск и Верный началось наступление царских войск против Кокандского ханства. Вскоре взяли штурмом крепость Аулие-Ата и город Туркестан, в сентябре Чимкент. Летом 1865 г. крупный экономический центр Ташкент был включен в состав России. В этом же году была образована Туркестанская область, Ташкент стал ее центром. Генерал-майор М. Г. Черняев высочайшим указом был назначен военным губернатором Туркестанской области (1828-1898 гг.) [Васильев 2018: 32]. В 1866 г. были завоеваны Худжанд, Ура-Тюбе, Джизак и другие города. В 1868 г. после военных неудач Бухарское и Кокандское ханства признали себя вассалами Российской империи. В итоге русские купцы получили право на беспошлинную торговлю на территории этих ханств [Халфин 1965: 238-239].

Одним из участников этих среднеазиатских походов был Мирсалих Мирсалимович Бекчурин (1819-1903 гг.) В 1865 и 1866 гг. при генерале Н. А. Крыжановском (1818-1888 гг.), командующем войсками Оренбургского военного округа, он два раза был в Средней Азии в качестве переводчика с восточных языков. Участвовал во всех походах, организованных под личным руководством Н. А. Крыжановского, находился рядом с генералом при штурме городов Ура-Тюбе и Джизак, по его поручению вел переговоры со среднеазиатскими властями.
М. Бекчурин, кроме дипломатической деятельности в период присоединения Средней Азии, широко известен как башкирский просветитель, педагог, ученый-лингвист и фольклорист [ВИБ 2013: 93].

В последующем М. Бекчурин опубликовал свои наблюдения. В основном он уделяет внимание не военным действиям, а социально-экономическому развитию региона. Достаточно подробно характеризует крепости и города Худжанд, Нау, Ура-Тюбе, Замин, Джизак и Чим-Курган. Описывает этнический состав городов, основные занятия населения, с кем и чем торгуют, дороги, расстояние между городами, отношения между соседними городами и странами и т. д. Например, о Худжанде М. Бекчурин пишет, что город значительно населен, жители в основном таджики и сарты. Число всех живущих в городе и окрестностях от 40 до 45 тыс. «Усердие их к вере» отчасти видно уже из того, что в городе 160 мечетей [Бекчурин 1872: 3].

Промышленность в Ходженте, как вообще в Туркестанской области, находится в зачаточном состоянии. Торговля в сравнении с Ташкентом незначительна, но через город беспрестанно проходят караваны из Бухары в Коканд. Они останавливаются здесь единственно для внесения пошлин за провозимые товары. Русские товары («ситцы, сукна», железные и медные изделия и сахар) получают из Ташкента, куда они привозятся из Петропавловска, Троицка и Оренбурга [Бекчурин 1872: 2-3]. Поскольку Ташкент являлся крупным экономическим центром, его завоевание широко комментировалось в деловых и военно-политических кругах России. Подчеркивалось важное значение города как торгового центра, который может принять роль главного рынка для всей Средней Азии; отмечалось богатство региона полезными ископаемыми [Халфин 1965: 196]. В последующем Ташкент действительно становится не только огромным внутренним рынком, но и центром русско-среднеазиатской торговли [Волков 2015: 83].

М. Бекчурин в своих заметках интересно описывает мавзолей Ходжи Ахмета Ясави, который находился в г. Туркестан, дает историческую справку с момента основания, описывает состояние, внутреннюю отделку, приводит переводы настенных над- 
писей с арабского и персидского языков. Им перечислены даже имена духовных лиц, состоявших тогда на службе при мечети. Как отмечает автор, «во время штурма города мечеть испытала повреждения, но она могла быть разрушена или пострадать больше, если бы шейх-эль ислам, пренебрегая грозившею ему опасностью, не поспешил сам взойти на минарет и не поднял белого флага, предвестника сдачи города» [Бекчурин 1872: 63].

По записям М. Бекчурина можно предположить, что первоначально его наблюдения были написаны в форме отчета. Лично участвуя в переговорных процессах с среднеазиатскими властями, все же он акцентирует внимание на изложении экономического развития этого обширного региона. Одновременно вносит свои предложения для улучшения торговли между Россией и ханствами Средней Азии. Например, для улучшения развития торговли он предлагает скорее построить железную дорогу от Оренбурга до Самары и Моршанска [Бекчурин 1872: 49]. Особенно сведения экономического характера были ценными для правительства в этом стратегическим регионе, где пересекались важные транзитные торговые пути.

В юго-восточной внешней политике России Мирсалих Бекчурин был не первым участником из семьи Бекчуриных. Его отец Мирсалим Бекчурин входил в состав посольства Я. П. Гавердовского, организованного в 1803 г. в Бухару. В это время он служил помощником пакгаузного инспектора Оренбургской таможни. Как хорошо знавшего местные языки и нравы Бухары, Мирсалима Бекчурина включили в состав посольства в качестве переводчика [Халфин 1974: 62].

Династию продолжил сын Мирсалиха Бекчурина Мирюсуф Бекчурин, который после окончания курса в Неплюевском кадетском корпусе в 1867 г. участвовал в Бухарском, Хивинском и Кокандском походах. В одном из среднеазиатских арабографичных источников упоминаются некоторые стороны деятельности Мирюсуфа Бекчурина. Казахский ученый Т. К. Бейсембиев приводит интересные сведения о Мирюсуфе Бекчурине как представителе новой русской администрации из исторической хроники «Тасниф-и гариб», написан- ной на тюрки. В документе сообщается, что служившие в городе Маргилан Бекчурин, Томич и Баранов были лучшими начальниками, не брали взяток и достойно относились к подданным [Бейсембиев 2009: 132].

Путевые записи солдата Хуснияра в свете других сведений о Ферганском отряде и его походе

Известны арабографичные источники, авторами которых являются солдаты из числа башкир - участников среднеазиатских походов. Некоторые из них опубликованы С. А. Искандаровой [Искандарова 2020: 231-246]. Мы хотели остановиться на еще одном интересном источнике. Это путевые записи башкирского солдата Хуснияра, также участника среднеазиатских походов. Рукопись не имеет названия, написана на арабографичном тюрки. Автор в своем автобиографическом стихотворном произведении описывает период прохождения службы в Средней Азии. Источник хранится в Фонде рукописей Института истории, языка и литературы Уфимского федерального исследовательского центра РАН (далее - ИИЯЛ УФИЦ РАН) [ФР ИИЯЛ УФИЦ РАН. 1 аэ.].

Данный источник условно можно разделить на две части. В первой автор повествует о периоде от получения известия о призыве до отбытия из г. Бирск в Среднюю Азию. Во второй части содержится непосредственно изложение периода несения службы.

Хуснияр родом из деревни Старокочкильдино Бирского уезда. Согласно источнику, во время учебы в медресе деревни Старотазларово приезжает его отец с вестью о призыве на службу. Попрощавшись, Хуснияр с отцом возвращаются в Старокочкильдино, пробыв там два дня, едут на «прием». Автор не называет населенный пункт «приема», это, должно быть, уездный центр - город Бирск. Далее описывается интересный случай набора солдат. Новобранцы должны тянуть номера: «сказали на приеме тянуть номера, испытать свое счастье... Хуснияр вытянул номер 109, много людей взяли, у кого дальние номера - остались» [ФР ИИЯЛ УФИЦ РАН. 1 аэ. Л. 26-27]. Таким образом, понятно, по какому принципу шел набор призывников: в список попали те, кому достались номера 
от начала нумерации до определенного числа, обозначавшего количество новобранцев.

После прохождения медосмотра ему окончательно сказали, что он годен для военной службы, и вручили «билет» явиться 18 декабря в г. Бирск. В истечении 35 дней он прибывает к месту назначения, и через 4 дня новобранцы направляются в г. Уфу, далее в Оренбург и через казахские степи в Среднюю Азию. Здесь автор не называет, в какое время происходят события, но, как понятно из последующего изложения фактов, это декабрь 1877 г.

Спустя 35 дней, претерпев жару, песчаные бураны и другие муки, новобранцы добираются до города Казалы. Пробыв там три дня, двигаются дальше вдоль реки Сырдарья и доходят до города Ак Мечеть. Через два дня следуют далее, очередную остановку совершив в известном г. Туркестане. Здесь Хуснияр с удивлением восхищается величием мавзолея Ходжи Ахмета Ясави.

Далее через Чимкент новобранцы следуют в Ташкент - «крупный город, где живут разные люди ... уже под властью русских». Пробыв три дня, направляются в Худжанд, где Хуснияр случайно на улице встречает своего земляка Юсуфа из деревни Чураш, с которым они проводят целый день, знакомясь с городом [ФР ИИЯЛ УФИЦ РАН. 1 аэ. Л. 117]. Из города Худжанд направляются в Коканд, оттуда в город Маргилан. Остановки в этих городах, как и в предыдущих, были короткими. В целом до прихода их отряда в город Андижан все стоянки были не более двух-трех дней, о которых автор рассказывает поверхностно.

Достаточно подробно Хуснияр повествует о городе Андижан, отмечая «отрицательные» и «положительные» стороны его жизни. Здесь их расположили в казарме бывшей ханской мечети, где находилось медресе. Как верующего мусульманина и вчерашнего шакирда, это особенно сильно его удивило. Как отмечает сам автор, «при нахождении в мечети-казарме сжалось мое сердце» [ФР ИИЯЛ УФИЦ РАН. 1 аэ. Л. 130].

В числе поразивших Хуснияра как мусульманина фактов - употребление местными жителями наркотических веществ. Во-первых, это кальяны или «челем», как назвал их автор, которые курят все. Во-вторых, насваи, которые кладут под язык.
B-третьих, анаша и опиум, которые также употребляют местные жители. Автор с сожалением говорит об этих явлениях, отмечая, что мало кто не пробовал этого. Хуснияр критически относится к вопросу отношений между мужчинами и женщинами, к отсутствию порядка, чистоты и другим особенностям жизни местного населения. Необычными ему показались местные развлечения, бои баранов и петушиные бои за деньги. Кроме того, автор рассказывает о местной денежной единице, об успешном занятии андижанцев садоводством, земледелием и их быте [ФР ИИЯЛ УФИЦ РАН. 1 аэ. Л. 134-162].

Отряд продолжительное время находился в Андижане и в июне 1878 г. получил команду выдвигаться в Маргилан. Здесь был сбор и других формирований, перед которыми выступил командующий Ферганским отрядом генерал-майор А. К. Абрамов и объявил о походе в направлении Кашкадарьи. Сразу после обращения А. К. Абрамова под музыку оркестра солдаты начали походный марш [ФР ИИЯЛ УФИЦ РАН. 1 аэ. Л. 168-172].

Данный интересный фрагмент рукописи, повествующий о «походе в направлении Кашкадарьи», находит место и в других источниках и исследованиях, которые также отражают события, происходившие на китайской границе. Например, М. А. Терентьев, известный военный и востоковед, лично участвовавший в среднеазиатских походах, пишет, что крайне вызывающая политика Англии во время русско-турецкой войны в 1877 г., а затем на Берлинском конгрессе в июне 1878 г. навели российское правительство на мысль воспользоваться новыми позициями в Средней Азии, относительная близость которых к английским владениям Ост-Индии давала возможность наделать англичанам достаточно хлопот и тем отвлечь их от вмешательства в чужие дела [Терентьев 1906: 427].

Другой исследователь, В. Н. Зайцев, в своей работе также отмечает, что в июне 1878 г. был сформирован Ферганский отряд под начальством генерала-майора А. К. Абрамова. Начальное движение предполагалось к афганской границе в связи со сложностями, сложившимися в политических отношениях с английским правительством. Но затем этому отряду была назна- 
чена другая цель - двигаться в сторону кашгарской границы для поддержания требований о свободном пропуске наших торговых караванов, так как, по случаю волнений в это время в Кашгаре и бегства многих кашгарских жителей вместе с эмиром в русские пределы, китайское правительство запретило переходить за границу российским купцам [Зайцев 1882: 206]. Таким образом, первопричиной похода стало осложнение отношений Российской империи с Англией, но в последующем цель, поставленная перед выступившими в поход, изменилась.

Ферганский отряд, выдвинувшись из Маргилана через поселение Шахимардан, доходит до высоких снежных вершин, но из-за сугробов «девять аршинов» не смог продолжить маршрут в сторону Кашгара. В итоге отряд повернул обратно в Шахимардан, затем последовал в город Ош, оттуда в город Гульча. Далее измотанный отряд по узким тропам через вершины Алайских гор следует к местечку Иркестам (или Иркештам). Там он оставался некоторое время, успев построить одно «сооружение» [ФР ИИЯЛ УФИЦ РАН. 1 аэ. Л. 173-176].

Высокогорный перевал, описываемый Хуснияром, при переходе которого возникли сложности из-за непогоды, скорее всего, называется Кара-казык. Как отмечает М. А. Терентьев, генерал-майор А. К. Абрамов лично осмотрел перевал Кара-казык и решил, что все вещи придется переносить на руках, что крайне измотает солдат и будет сопровождаться большой потерей времени. Воспользовавшись двухдневной благополучной погодой, он смог организовать прохождение перевала только двумя ротами с инженерным парком. Остальной отряд повернул назад в г. Ош. Затем из Оша они выступили, согласно прежнему плану, по дороге в Кашгар, через город Гульчу, для того чтобы построить укрепление в Иркештаме. Это было вызвано враждебным отношением китайских властей на данном участке границы [Терентьев 1906: 437].

Из Иркештама отряд выдвигается в сторону Кашгара, переходит большую реку с сильным течением. Он приближаются к Кашгару (оставалось всего 30 км), но город был в составе Китая. Здесь состоялась встреча с китайскими послами, и Хуснияр кратко упоминает об этом. Солдатам, которые впервые увидели жителей Поднебес- ной, даже от их внешнего вида стало «не по себе»: они удивлялись языку китайцев, длинным волосам, как у женщин, и длиннополой одежде, как у попов [ФР ИИЯЛ УФИЦ РАН. 1 аэ. Л. 176-178].

Как следует из рукописи Хуснияра, вооруженных столкновений не было. Отряд несколько дней дислоцировался на этом месте, но затем солдаты, измученные переходами и постепенным истощением продовольственных запасов, вернулись обратно в Андижан.

Относительно отправки солдат к местечку Иркештам и их возвращения В. Н. Зайцев пишет следующее: в «На Алайскую долину, по примеру прошлого года для обеспечения спокойствия в горах, был выслан самостоятельный отряд, в котором находилась 1-я рота с 22 июня по 12 октября, эту роту предполагалось оставить в урочище Иркештан, для чего в этом урочище было выстроено помещение для зимовки; но по изменившимся обстоятельствам, казарма была разрушена, рота вернулась домой и на границе войск не осталось» [Зайцев 1882: 206-207]. М. А. Терентьев вносит ясность по данному вопросу и отмечает, что 1 октября Ферганский отряд, не добившись своим пребыванием в Иркештаме никаких уступок от китайцев по отношению к российским купцам, выступил обратно в Фергану на зимние квартиры [Терентьев 1906: 441].

Описывая весь свой маршрут, автор анализируемой рукописи - солдат Хуснияр - не сообщает, в какой именно части он нес службу. Ознакомившись с материалами М. А. Терентьева и В. Н. Зайцева, сопоставив их с сведениями Хуснияра, можно сказать - это Ферганский отряд под командованием генерала-майора А. К. Абрамова. Данное формирование состояло из 6 стрелковых рот разных линейных батальонов, трех сотен 5-го сводного полка, 6 орудий конно-горной и дивизиона ракетной батареи [Терентьев 1906: 434].

\section{Заключение}

В XXI в. Средняя Азия остается стратегически важным регионом для России как в политическом, так и в экономическом отношении. На ее обширной территории, за которую Россия боролась полтора века назад и на которой тогда укрепила свои позиции, расширив границы далеко на юг, в настоя- 
щее время располагаются независимые государства. Но даже спустя столько времени основными игроками во внешнеполитической арене в этом районе являются Россия, Китай, а вместо Великобритании появились США. Выгодное географическое расположение территории Туркестана представляется идеальной площадкой для больших геополитических проектов.

Крупный, преимущественно мусульманский, регион в этническом плане далеко неоднороден. Как свидетельствуют исторические факты, на этой территории отношения между ханствами и народами не всегда были дружественными. Здесь соседствовали кочевые народы и оседлые земледельцы, бескрайние степи, пустыни и крупные города Бухара, Самарканд которые были центрами политической, экономической и культурной жизни региона.

Все это разнообразие требовало больше информации для понимания, ознакомления с населением, их основными занятиями, от-

\section{Источники}

ФР ИИЯЛ УФИЦ РАН. 1 аэ. - Фонд рукописей Института истории, языка и литературы Уфимского федерального исследовательского центра РАН. Личный фонд академика Г. Б. Хусаинова. 1 археографическая экспедиция.

\section{Литература}

Бартольд 1977 - Бартольд В. В. Сочинения. T. IX. М.: Наука, 1977. 966 с.

Бейсембиев 2009 - Бейсембиев T. К. Кокандская историография: Исследование по источниковедению Средней Азии XVIII-XIX веков. Алматы: TOO «Print-S», 2009. 1263 с.

Бекчурин 1872 - Бекчурин M. M. Туркестанская область: Заметки статского советника Бекчурина. Казань: Унив. тип., 1872. 70 с.

Буканова 1997 - Буканова Р. Г. Города-крепости юго-востока России в XVIII веке: История становления городов на территории Башкирии. Уфа: Китап, 1997. 253 с.

Васильев 2018 - Васильев Д. В. Бремя империи. Административная политика России в Центральной Азии. Вторая половина XIX в. М.: Политическая энциклопедия, 2018. 638 с.

Витевский 1889 - Витевский В. Н. И. И. Неплюев и Оренбургский край в прежнем его ношениями между частями населения и их соседями и т. д.

Для восстановления и представления исторической картины данного периода в Туркестане необходимо привлечение многочисленных материалов из отчетов, журналов, дневников, путевых записей и т. д. Анализ рукописных источников на арабографичном письме тюрки имеют большое научное и практическое значение для изучения этнополитической истории на территории Средней Азии.

Сведения статского советника М. Бекчурина и рядового солдата Хуснияра дополняют базу источников по юго-восточной политике Российской империи и ходу освоения обширной территории во второй половине XIX в. Второй источник долгое время оставался вне поля зрения исследователей, так как написан на тюрки. К сожалению, сегодня значительное количество подобных документов многих российских архивов не введены в научный оборот.

Sources
Institute of History, Language and Literature;
Ufa Federal Research Centre of the RAS;
Manuscript Collection. (In Bash.)

составе до 1758 г. Вып. І. Казань: типо-лит. В. М. Ключникова, 1889. 176 с.

ВИБ 2013 - Военная история башкир: энциклопедия / гл. ред. А. З. Асфандияров. Уфа: Башк. энцикл., 2013. 432 с.

Волков 2015 - Волков И. В. Россия и Восток: Туркестанский азимут (вторая половина XIX - начало XX вв.) // Труды X Всероссийского съезда востоковедов, посвященного 125-летию со дня рождения выдающегося востоковеда Ахмет-Заки Валиди Тогана. Кн. 1. Уфа: ИИЯЛ УНЦ РАН, 2015. С. 81-84. Зайцев 1882 - Зайцеев В. Н. История 4-го Туркестанского линейного батальона, с картой, за период с 1771 по 1882 год, как материал к описанию движения русских в Среднюю Азию. Ташкент, 1882. 283 с.

Искандарова 2020 - Искандарова С. А. Цикл баитов о войне с Кокандским и Бухарским ханствами во второй половине XIX в. // 
Письменные памятники западных и северо-западных районов Башкортостана: статьи и материалы. Уфа: ИИЯЛ УФИЦ РАН, 2020. C. 231-246.

Соловьев 1963 - Соловьев С. М. История России с древнейших времен. Кн. IX. Т. 17-18. М.: Соцэкгиз, 1963. $701 \mathrm{c.}$

Терентьев 1906 - Терентьев М. А. История

\section{References}

Asfandiyarov A. Z. et al. (eds.) Bashkir Military History: Encyclopedia. Ufa: Bashkirskaya Entsiklopediya, 2013. 432 p. (In Russ.)

Barthold V. V. Collected Works. Vol. IX. Moscow: Nauka, 1977. 966 p. (In Russ.)

Bekchurin M. M. Turkestan Oblast: Notes by State Councilor Bekchurin. Kazan: Imperial Kazan University, 1872. 70 p. (In Russ.)

Beysembiev T. K. Kokand Historiography: Exploring Central Asian Source Studies, $18^{\text {th }}$ $19^{\text {th }}$ Centuries. Almaty: Print-S, 2009. 1263 p. (In Russ.)

Bukanova R. G. Fortified Settlements of Southeastern Russia, $18^{\text {th }}$ Century: History of Urban Development in Bashkiria. Ufa: Kitap, 1997. 253 p. (In Russ.)

Iskandarova S. A. Baits about wars against the Khanates of Kokand and Bukhara: mid-to-late $19^{\text {th }}$ century. In: Written Monuments of Western and Northwestern Bashkortostan. Articles and Materials. Ufa: Institute of History, Language and Literature (Ufa Fed. Res. Centre of RAS), 2020. Pp. 231-246. (In Russ.)

Khalfin N. A. Russia and Central Asian Khanates: Early-to-Mid $19^{\text {th }}$ Century. Moscow: Nauka, 1974. 406 p. (In Russ.) завоевания Средней Азии. Т. 2. СПб.: Типолит. В. В. Комарова, 1906. 555 с.

Халфин 1965 - Халфин Н. А. Присоединение Средней Азии к России. (60-90-е годы XIX в.). М.: Наука, 1965. 468 с.

Халфин 1974 - Халфин Н. А. Россия и ханства Средней Азии (первая половина XIX в.). М.: Наука, 1974. 406 с.

Khalfin N. A. The Russian Annexation of Central Asia: 1860s - 1890s. Moscow: Nauka, 1965. 468 p. (In Russ.)

Solovyov S. M. History of Russia: From Earliest Times. Book IX. Vols. 17-18. Moscow: Sotsekgiz, 1963. 701 p. (In Russ.)

Terentyev M. A. The Russian Conquest of Central Asia. Vol. 2. St. Petersburg: V. Komarov, 1906. 555 p. (In Russ.)

Vasilyev D. V. The Burden of Empire: Russia's Administrative Policies in Central Asia, Midto-Late $19^{\text {th }}$ Century. Moscow: ROSSPEN, 2018. 638 p. (In Russ.)

Vitevsky V. N. Ivan I. Neplyuev and Orenburg Region in Its Pre-1758 Borders. Vol. I. Kazan: V. Klyuchnikov, 1889. 176 p. (In Russ.)

Volkov I. V. Russia and the East: Turkestan azimuth, mid- $19^{\text {th }}-$ early $20^{\text {th }}$ centuries. In: National Congress of Orientalists Celebrating the $125^{\text {th }}$ Anniversary of Zeki Velidi Togan's Birth. Vol. 1. Ufa: Institute of History, Language and Literature (Ufa Scientific Centre of RAS), 2015. Pp. 81-84. (In Russ.)

Zaytsev V. N. A History of the $4^{\text {th }}$ Turkestan Line Battalion Supplemented with a Map, 1771 - 1882: Materials on the Russian Invasion of Central Asia. Tashkent, 1882. 283 p. (In Russ.) 